\title{
Attitude and Motivation affects English Language Proficiency of Engineering students: A Preliminary survey through adapted Attitude/Motivation Test Battery
}

\author{
Jayanti Shinge ${ }^{1}$, Sanjay Kotabagi ${ }^{2}$ \\ ${ }^{1}$ Faculty, Department of Humanities and Social Sciences, KLE Technological University, Hubli, Karnataka. \\ ${ }^{2}$ Head of the Department of Humanities and Social Sciences, KLE Technological University, Hubli, Karnataka. \\ 1jayanti_s@kletech.ac.in \\ ${ }^{2}$ sanjay_kotabagi@kletech.ac.in
}

\begin{abstract}
:
Language proficiency is one domain everybody on earth wants to conquer. Administering language proficiency into oneself is not a cakewalk. There is a dire need to explore and better understand how factors like attitude and motivation affect the language proficiency of engineering students.
\end{abstract}

Motivation is an integral part of almost everything we do in day to day life. It becomes an essential component when we are working towards imbibing some skills into ourselves as a trait. Lack of motivation will never lead us to make ourselves a skilled person. Attitude too is also a stepping stone towards being skilled. Today's engineers are defined by their effective skills and not based on their grade cards. This research tries to find to what extent engineering students' English language proficiency gets affected by the attitudes and motivation they carry towards English as a language.

R. C Gardener's Attitude/ Motivation Test battery Questionnaire was adapted for conducting the quantitative survey. This study is also focused on enhancing the theoretical knowledge about how the factors like motivation and attitude towards the English language can affect the language proficiency of students.

The respondents included freshman engineering students. The analysis shows that majority of the students do have a positive inclination and attitude towards the English language. The attitude and motivation can get affected by the course content, pedagogy, and assessment of the course at the university level. The relationship between the language trainers and students has a stake in affecting the levels of motivation and attitude of the students towards the English

language. Students are highly motivated towards the English language to have shown a $100 \%$ inclination towards improvement during the semester. One on one interviews with the student and classroom observations have shown high motivation and positive attitude towards the English language has a tremendous effect on the proficiency levels of the students.

English language proficiency enhances the competency of engineering students. Conducive and a healthy environment with a well-designed course can foster students' English language skills. The effectiveness of the language can not only help them in in-classroom assessment but also fare better during their on-campus placement interviews.

Keywords: Motivation, Attitude, Language, Proficiency, Engineers.

\section{Introduction:}

Poor English language proficiency may be keeping a large number of India's engineers from landing some of the bestpaid jobs in the country. A study has found that an overwhelming 97 percent of engineers in the country cannot speak English, required for high-end jobs in corporate sales and business consulting. Moreover, as per the report based on the study, about 67 percent of engineers graduating from India's colleges do not possess spoken English skills required for any job in the knowledge economy.

The study, 'The National Spoken English Skills of Engineers Report', conducted by Aspiring Minds, surveyed the study of the English skills of 30,000 engineers across 500 engineering colleges. Although the problem is far more pronounced in tier 2 and tier 3 colleges, instilling spoken English skills is a big challenge in Indian Institutes of Technology and National Institutes of Technology as well. About 600,000 engineers graduate annually in India.

"We get students from different background regions, and they are mostly not comfortable with English," said Gautam Biswas, Director, IIT Guwahati. "Quite a few students appear for the joint entrance examination in their mother tongue. It becomes very difficult for them to follow the curriculum." 
UB Desai, director of IIT Hyderabad, said the problem of students not being able to speak English is not restricted to IITs but is prevalent across the country, and even in China and a few European nations. "Over the years, the focus in the education system has shifted to chemistry, maths, and physics. Focus on soft skills has reduced. Students may lose out on good job prospects as many companies come to campuses for global positions as well," he said.

Engineering students in the metros do much better in spoken English skills than those in the non-metros, according to the study. Kushal Sen, dean - faculty at IIT Delhi, affirms this. "A majority of our students may not have the problem of speaking in English but about 30 percent need to be groomed when it comes to soft skills," he said. IIT Delhi offers its students courses in soft skills.

Tier- 1 colleges fare better in spoken English skills than their peers down the line. "As expected the spoken English ability of candidates becomes worse, on average, on campuses in lower-tier cities," said Varun Aggarwal, co-founder, and chief technology officer, Aspiring Minds.

Recruiters and HR managers around the world report that candidates with English skills above the local average stand out from the crowd and garner 30-50 percent higher salaries than similarly qualified candidates without English skills, according to Aggarwal. "The trends in India are no different, with English fluency being one of the key qualities recruiters look for during the interview," he said.

IIT Madras's dean (planning) R David Koilpillai said, "Students must be able to communicate technical ideas clearly in interviews. Proficiency in spoken English gives confidence." In the past two-three years, NIT Trichy has taken corrective measures in this regard. "Students not able to speak or even understand lectures in English is a major problem," said Srinivasan Sundarrajan, director. The institute organizes bridge courses, workshops, and orientations for the students. "The seniors at our institute help out juniors," said Sundarrajan.

The key problem faced by engineers is pronunciation, followed by fluency skills, grammar, and sentence construction. Engineers show a larger gap in elements of spoken English, pronunciation, and fluency, followed by grammar, though they do relatively better in vocabulary and understanding English. As per the report, only 6.8 percent of engineers show the ability to speak or respond spontaneously.

English is the global language of business and indeed enterprise. The situation is unlikely to change in a globalized economy in the future. Therefore, proficiency in English must be seen as a necessary skill and some ingredient for a post-colonial cultural debate.

\section{Background:}

The realm of engineering is on a roller coaster ride and is undergoing a paradigm shift. It is no more producing mere engineers but producing a product, laden with all the features and attributes the outside world is demanding. This necessitates a university like ours, KLE Technological University, to know what the industrial requirement is and change the modules accordingly. The list of the requirements is a very exhaustive one, which demands us to be on toes round the clock and find answers. We strive hard to work on our students and launch them as the best in the evolving and volatile job market. Even after giving our best, we face challenges in the form of "poor English Language Proficiency of the engineering students". This initial curiosity led to finding the various factors which affect the English Language Proficiency of the students.

The KLE Technological University has taken initiations to hone students' communication skills across their engineering journey. In the very first year, a 2 credit course called Professional Communication is offered with the following course objectives,

1. Express themselves in grammatically correct language in real-life situations.

2. Enhance comprehending ability in oral/written skills.

3. Acquire proficiency in written communication.

4. Work in teams to gain interpersonal skills, time management skills, and presentation skills to present their views on any given topic.

An ambitious program is introduced which is spread across the second and the third year of the engineering curriculum to heighten the overall development of a student's personality. The program concentrates on:

1. Enhancing the employability of the students and prepare them for the corporate world

2. Developing professional skills

3. Inducing the analytical and mathematical abilities and language comprehension

The following shows a glimpse of the modules that are covered under the interventions for uplifting students' English language skills.

\begin{tabular}{|l|l|}
\hline Professional Communication - First Year & Hrs \\
\hline \multicolumn{1}{|c|}{ Modules } & \\
\hline $\begin{array}{l}\text { Basics- English Communication } \\
\text { Course Introduction, Explanation of template } \\
\text { mix-ups with correct usages \& necessity of } \\
\text { grammar in error detection, Usage of tenses }\end{array}$ & $9 \mathrm{hrs}$ \\
\hline $\begin{array}{l}\text { Vocabulary and Grammar } \\
\text { Vocabulary, Word Formation and Active and } \\
\text { Passive Voice }\end{array}$ & $6 \mathrm{hrs}$ \\
\hline
\end{tabular}




\begin{tabular}{|l|l|}
\hline Bouncing Practice & $6 \mathrm{hrs}$ \\
$\begin{array}{l}\text { Definition and types of bouncing and its practice } \\
\text { with examples, reading skills, freestyle speech. } \\
\text { Individual presentation. }\end{array}$ & $8 \mathrm{hrs}$ \\
\hline $\begin{array}{l}\text { Rephrasing and Structures } \\
\text { Comprehension and Rephrasing, PNQ Paradigm } \\
\text { and Structural practice }\end{array}$ & $3 \mathrm{hrs}$ \\
\hline $\begin{array}{l}\text { Dialogues } \\
\text { Introduction of dialogues, Situational Roleplays, }\end{array}$ & $9 \mathrm{hrs}$ \\
\hline $\begin{array}{l}\text { Business Communication } \\
\text { Covering letter, formal letters, Construction of } \\
\text { paragraphs on any given general topic. }\end{array}$ & \\
\hline
\end{tabular}

(Table 1: Professional Communication - Modules)

For the second year, the following modules are delivered as part of VIKAS,

\begin{tabular}{|l|l|}
\hline VIKAS 2-year & Hrs \\
\hline Communicate with confidence: & \\
\hline Tools of communication Active Listening & $\mathbf{6 ~ h r s}$ \\
\hline Body Language & \\
\hline Voice and Verbal Language & \\
\hline The Zero Presentation & \\
\hline Living with Stage(any) Fear & \\
\hline Engineers! Feedback matters! & \\
\hline Captivating the audience & $\mathbf{6 ~ h r s}$ \\
\hline The Verbal Impression (WE) & \\
\hline Are you shy? Linguistically? & \\
\hline Get rooty! & \\
\hline Opposites Attract? & $\mathbf{6 ~ h r s}$ \\
\hline Perfect Presenter (PS) & \\
\hline The Zero Presentation & $\mathbf{6 ~ h r s ~}$ \\
\hline Overcoming with Stage(any) Fear & \\
\hline Engineers! Feedback matters! & \\
\hline Captivating the audience & $\mathbf{4} \mathbf{h r s}$ \\
\hline Written English (WE) & \\
\hline Analogies & \\
\hline Sentence Completion & \\
\hline Group Discussions (GD) & \\
\hline Basics & \\
\hline Introduction & \\
\hline Parameters evaluated & \\
\hline Conclusion and practice & \\
\hline Spoken English (SE) & \\
\hline Introduction to IPA & \\
\hline Sounds in English & \\
\hline
\end{tabular}

\begin{tabular}{|l|l|}
\hline Word Stress & \\
\hline Pausing and Rhythm & \\
\hline
\end{tabular}

(Table 2: VIKAS 2 year Modules)

For the third year, the VIKAS program offers the following modules,

\begin{tabular}{|l|l|}
\hline \multicolumn{1}{|c|}{ VIKAS 3 - Year } & Hrs \\
\hline Personal Interviews (PI) & \\
\hline FAQs in a personal / HR interview & $\mathbf{6 ~ h r s ~}$ \\
\hline Understanding Interviewer Psychology & \\
\hline Interview Etiquette & \\
\hline The Verbal Impression (WE) & $\mathbf{4}$ hrs \\
\hline Comprehend! It pays off! & \\
\hline Successful Job Applications (RW) & $\mathbf{4}$ hrs \\
\hline Résumé Writing & \\
\hline Covering Letter/Email & \\
\hline Advanced Group Discussions (AGD) & $\mathbf{6 ~ h r s ~}$ \\
\hline Recap of basics & \\
\hline Mock GDs & \\
\hline Case Studies & \\
\hline Written English (WE) & $\mathbf{6 ~ h r s ~}$ \\
\hline $\begin{array}{l}\text { Questions from Placement Tests and } \\
\text { Competitive Exams }\end{array}$ & \\
\hline Error Correction & $\mathbf{6 ~ h r s ~}$ \\
\hline Written Communication (WC) & \\
\hline Paragraph Writing & \\
\hline Essay Writing for Placement Tests \\
\hline
\end{tabular}

(Table 3: VIKAS 3 year Modules)

VIKAS offers a total of 64 hours of training for every student on campus. Although the university has laid a healthy foundation for students to hone their English language proficiency there has been a constant comment on the effective communication skills of the students by the mass recruiters and an array of other important recruiters who have been visiting campus for both IT and Non-IT jobs. The following table shows the comments students received during their interviews.

Few Sample Comments Received by the Recruiters Areas of Improvement:

Student 1

- Many mistakes in Spoken English.

- Should be loud and clear

- Thought process needs improvement

- Open mouth and speak for clarity.

- A strong regional language influence as she translates in regional language to English Grammar. 
- $\quad$ Needs improvement along with pronunciation and vocabulary.

- Very nervous should work on confidence level.

- Avoid Jargons.

- The rate of speech is high.

\section{Areas of Improvement:}

Student 2

- Should work hard on all parameters as she has no confidence at all.

- Work on Grammar

- Especially Tenses

- Plural forms.

- Basic sentence structures

- Body language

- Use gestures

- Have a pleasant demeanour

Areas of Improvement:

Student 3

- Ready to learn

- Open to have a conversation

- Enthusiastic

- Specific mistakes in Spoken English

- Should work on jargon and grammar.

- Should have more clarity in the thought process as was running.

Short of words.

- Avoid repetition of certain words.

- The rate of speech is high.

- Choice of words needs improvement along with pronunciation.

Areas of Improvement:

Student 4

- Well-groomed

- Considerate and compassionate.

- Open to suggestions.

- Read and analyse more.

- Read to expand knowledge and analyse before your answer.

- Should work on jargon and grammar.

- Should have more clarity in the thought process as was running.

- Avoid repetition of certain words.

- The rate of speech is high.

- Choice of words

- Needs improvement along with pronunciation

(Table 4: Comments Received by Recruiters)
The study thus tries to find the answer to how the psychological factors like attitudes and motivation of students affect the English language proficiency of the students as the literature review revealed and quantified a major role of the psychological factors also termed as an affective filter

The hypothesis examined through this study is that there is a positive correlation between attitudes and motivations of the students towards their English language.

\section{Literature Review}

One of the most successful language learning experiences took place towards the end of the Second World War when the American military needed to train their personnel in the languages of the countries they would have to administer and/or deal with. In short intensive courses, the students learned amazingly fast. Similarly in Britain, Air Force personnel were taken to Cambridge and taught Russian with enormous success. Whatever the teaching methods used- or the reasons for the language learning-the teachers and students in these cases had several things in favor of them. They were highly motivated, they wanted to learn and they had strong reasons for doing so with a fear of failure. The desire to learn can come from many causes. Perhaps the students love the subject or are simply interested to see what it is like. On the other hand, they may have a practical reason for their study: learn English so they can watch American TV or work with English people or proficient with the English language can offer them a better chance at the job market.

Kachru (1992) discussed the role of learners' attitude in choosing the variety of English: "What does such an attitude imply? In Ghana, for example, educated Ghanaian English is acceptable; but as Sey (1973, p.1) warns us, 'it does not entail competence in speaking RP since in Ghana 'the type that strives too obviously to approximate to RP is frowned upon as distasteful and pedantic'. In Nigeria, the situation is not different from Ghana or India (Kachru 1976 a). Bamghose (1971) emphasizes that "the aim is not to produce speakers of British Received Pronunciation (even if this were feasible) ... Many Nigerians will consider as affected or even snobbish any Nigerians who speak like a native speaker of English." An agreement between learners' attitudes and the type and amount of English that they learn is common in every L2 situation.

Sridhar (1994) points out: "SLA theory needs rebuilding from the ground up, to have a more functionally oriented and culturally authentic theory: why do models of second language acquisition (SLA) developed in the U.S. and Western Europe treat the vast majority of L2 learners, those that learn and use an L2 in non-native contexts, as marginal? The inescapable answer seems to be that current theories are powerfully constrained by Western cultural premises". Indeed, when discussing any issue about language teaching 
and learning, cultural differences should contribute tremendously to the initiative of the discussion. Issues may include the differences in educational systems, learning conditions, teaching and learning styles, learning differences between Western and Eastern cultures, and differences in needs for language use in the job market.

There has been a great deal of research on the role of attitudes and motivation in second language learning. The overall findings show that positive attitudes and motivation are related to success in second language learning (Gardner, 1985). It is not clear whether it is the motivation that produces successful learning or successful learning that enhances motivation or whether both are affected by other factors. Skehan (1989) noted that the question is, are learners more highly motivated because they are successful, or are they successful because they are highly motivated?

Motivation in second language learning is a complex phenomenon that can be defined in terms of two factors: learners' communicative needs and their attitudes towards the second language community. If learners need to speak the second language in a wide range of social situations or to fulfil professional ambitions, they will perceive the communicative value of the second language and will therefore be motivated to acquire proficiency in it. Similarly, if learners have favourable attitudes towards the speakers of the language, they will want more contact with them. Gardner and Lambert (1972) coined the terms integrative motivation to refer to language learning for personal growth and cultural enrichment, and instrumental motivation for language learning for more immediate or practical goals. Research has shown that these types of motivation are related to success in second language learning.

On the other hand, an individual's identity is closely linked with the way he or she speaks. It follows that when speaking a new language one is adopting some of the identity markers of another cultural group. Depending on the learner's attitudes, learning a second language can be a source of enrichment or a source of resentment. If the speaker's only reason for learning the second language is external pressure, internal motivation may be minimal and general attitudes towards learning may be negative. Moreover, one factor which often affects motivation is the social dynamic or power relationship between the languages. That is, members of a minority group learning the language of a majority group may have different attitudes and motivations from those of majority group members learning a minority language. Children as well as adults are sensitive to social dynamics and power relationships. Gardner and Lambert (1972) suggested that students who felt most warmly about a language and who wanted to integrate into the culture of its speakers are more highly motivated (and learned more successfully) than those who were only learning the language as a means to an end (e.g. getting a better job). In other words, Integrative motivation was more powerful than Instrumental motivation. But whatever kind of motivation students have, it is clear that highly motivated students do better than ones without any motivation at all.

Mohd Sallehhuddin (1994) surveyed 137 University Kebangsaan Malaysia (UKM) English non-major undergraduates to evaluate their attitudes towards English. This study concentrated mainly on the learners' attitudes towards the University's English language policy, their attitudes towards English vis-à-vis Bahasa Malaya, their views on speakers of English, and their attitudes towards the compulsory English language courses offered at UKM. The study showed that UKM students have positive attitudes towards the learning of English.

Mahreez (1994) undertook a study with 130 University Utara Malaysia English non-major undergraduates to assess their motivation and attitudes towards the English language. The study focused on some of the possible contributory factors that can affect the Chinese-Malaysian learners' attitudes and motivation, about the comparatively poor performances of the Malay and Indian learners. The results indicated that the attitudes and motivation of the above learners are 'positive and instrumental in orientation'.

Yang (2012) conducted a short study with 20 University Malaya Master students to gauge their attitudes and motivation in L2. The main objective of the study was to find out what makes some people acquire and learn English better than others. The findings reveal that 'learners who were highly and positively involved in their English proficiency had positive attitudes and highly motivated towards learning English'.

Latifah et al. (2011) directed massive research with 757 learners nationwide to assess how several factors like motivation, attitude, anxiety, and instrumental orientation play role in influencing learners' performance in the English language course in Open University Malaysia. The study shows that the above factors are correlated with learners' performance. While personal motivation plays an insignificant impact, attitude plays a positive impact on performance in the English course conducted at Open University Malaysia.

Al Mamun et al. (2012) conducted a questionnaire survey with 79 randomly selected non-major English undergraduate students from Khulna University, Bangladesh to gauge their attitude towards EFL. The research findings indicate that the learners have got a positive attitude towards the English language and their motivational orientation was instrumental

Chalak \& Kassaian (2010) conducted another study with 108 English translation major students at Islamic Azad University, Iran, and investigated their motivational orientation and their attitude towards learning English. The findings showed that these EFL learners tend to learn English for both instrumental and integrative reasons and their attitude towards the target language is generally highly positive. 
Galloway (2011) piloted research with 116 undergraduates from Kanda University of International Studies, Japan (a private university) to investigate these students' attitudes towards English and English teachers about the use of English as a lingua franca. The findings suggest that the learners deem English belonging to the native English speakers and they want to learn native English. The results highlighted that several factors influence students' attitudes.

Bobkina \& Fernandez (2012) investigated the motivational patterns and attitudes towards the use of English in social and educational contexts of 72 EFL engineering students at the Technical University in Madrid. They found that the predominant motivation among Spanish engineering students is extrinsic and most of the students have a positive attitude towards the social values and educational status of English. Moreover, students' have a positive orientation toward the English language.

Tahaineh \& Daana (2013) researched with 184 Jordanian EFL female undergraduates to measure out their motivational orientation and attitude towards learning the target language and its community. The results showed that the learners' motivation was instrumental in having utilitarian and academic reasons with the least impact of culture in it, whereas their attitude towards learning the target language and its community was highly positive.

Goktepe (2014) examined 90 first-year business studies undergraduates at a Turkish university and their attitude and motivation towards learning English as a foreign language. The results showed that these learners learn English mostly for instrumental reasons and also integrative motivation is the dominant motivational orientation for the learners to some degree.

Al Samadani \& Ibnian, S.S (2015) led a study with 112 English major students from Umm Al-Qura University, Saudi Arabia to explore their attitude as well as study factors affecting learning English. It also investigated the relationship between their attitudes and grade points average (GPA). The findings of the study revealed that the learners have an overall positive attitude towards English and that students with a high GPA have the highest positive attitude towards English, followed by the medium and the low GPA students.

\section{Research Phase:}

\section{What is an Affective Filter?}

Learning a language is a lot like being on a stage. And learners are trying to perform something for the first time, and that can be very uncomfortable. Stephen Krashen explains this concept Affective Filter, he refers to it as the complex emotions the students might have as they process the new information and try to produce the language.
When the affective filter is high, it means you are feeling a lot of emotions like annoyance, frustration, or anxiety. When the affective filter is low, it means you aren't nearly so stressed so the flow of information or talking about the knowledge can be more effective. There are some instances where students say, "I couldn't even remember simple things that I had accomplished yesterday in the class."

"Speaking became completely impossible because I focussed more on myself and the possible mistakes that I may make, that I couldn't remember a thing about what I was asked to speak on. The truth is the topic was not that difficult but I could not manage to speak and when and whatever I spoke didn't sound what I meant."

\section{What is Motivation?}

Motivation is often defined as the psychological quality that leads people to achieve a goal. For language learners, mastery of a language may be a goal. For Gardner et al. (1974) motivation comes from attitude and this attitude is a construct derived from a subject's answers to several questions. Gardner et al. (1974) divide this motivation into two types that depend on a different type of attitude.

\section{Types of Motivation}

Motivation is defined as the learner's orientation about the goal of learning a second language. It is divided into two basic types: integrative and instrumental.

\section{Integrative Motivation}

The learner's orientation concerning the goal of learning a second language means that learner's positive attitudes towards the target language group and the desire to integrate into the target language community (Crookes \& Schmidt, 1991).

\section{Instrumental Motivation:}

The learner's desire to obtain something practical or concrete from the study of a second language underscores his Instrumental motivation. The orientation underlies the goal to gain some social or economic reward through L2 achievement (Hudson, 1999).

\section{Trans-formative Motivation in Second Language Learning:}

Unlike the traditional motivational types in Second Language Learning, L2 Learners may be driven by a desire in which the learner transcends survival goal and seeks to learn and use the language as an empowerment tool to transform some aspects of his life, his community as well as that of the host community (Hashi, 2001).

\section{Characteristics of motivated learners:}


The author of a classic study of successful language learning concluded that the most successful learners are not necessarily those to whom a language comes very easily; they are those who display certain typical characteristics, most of them associated with motivation:

- Positive task orientation

- Ego involvement

- Need for achievement

- High aspirations

- Goal orientation

- Perseverance

- $\quad$ Tolerance of ambiguity (Naiman, 1978)

\section{Impact of motivation}

Following the socio-educational model, motivation to learn the second language includes three elements (Gardner \& Lambert, 1972):

- $\quad$ First, the motivated individual expends effort to learn the language.

- Second, the motivated individual enjoys the task of learning the language.

- Third, the motivated individual wants to achieve a goal.

\section{What is Attitude?}

The Longman Dictionary of Applied Linguistics and Language Teaching (2002, p.297) defines language attitudes as follows: "the attitudes which speakers of different languages or language varieties have towards each other's languages or to their language. Expressions of positive or negative feelings towards a language may reflect impressions of linguistic difficulty or simplicity, ease or difficulty of learning, degree of importance, elegance, social status, etc. Attitudes towards a language may also show what people feel about the speakers of that language. Language attitudes may affect second language or foreign language learning. The measurement of language attitudes provides information which is useful in language teaching and language learning."

In his initial work on motivation, Gardner included the concept of attitudes as an important component of success in second language acquisition. He claimed that attitudes and motivation are often treated together - given that attitudes have motivational properties and motivation has attitudinal implications\| (Gardner, 2008, p. 31). He has always maintained that the learners' attitude towards the target culture will have an impact on the level of success when learning a second language. He said: The words, sound, grammatical principles, and the like that the language teacher tries to present are more than aspects of some linguistic code; they are integral parts of another culture. As a result, students' attitudes toward the specific language group are found to influence how successful they will be in incorporating aspects of that language. (Gardner, 1985, p. 6)

The importance of attitudes in the second language resides in the idea that if the attitudes towards the target culture are positive, the learner will be more motivated to learn the target language, and if the attitudes are negative, the opposite will be true as

Gardner (1985) explains, in the language learning situation, if the students' attitudes are favourable, it is reasonable to predict, other things being equal, that the experience with the language is pleasant, and the students will be encouraged to continue. Simply, favourable attitudes tend to cause the experience to be perceived positively. If, on the other hand, attitudes are negative, the experiences will tend to be perceived unfavourably. (p. 8)

Gardner (1985, p. 9) defines an individual's attitude as —an evaluative reaction to some referent or attitude object [attitudes toward something, e.g. attitudes towards Frenchspeaking people'], inferred based on the individual's beliefs or opinions about the referent.\| More recently, Oskamp and Schultz (2005, p. 9) defined an attitude as a - predisposition to respond favourably or unfavourably concerning a given attitude object.\| Attitude is thus linked to a person's values and beliefs and - promotes or discourages the choices made in all realms of activity, whether academic or informall (Mc Groarty, 1996. p. 5). Learning occurs more easily when the learner has a positive attitude towards the language and learning (Chamber, 1999).

This current study was done with academic inquisitiveness and the desire to know the engineering students' learners' responses and reactions to learning the English language as a second or foreign language at the tertiary level.

\section{Methodology}

To check how engineering students are affected by factors like motivation and attitude AMTB questionnaire was adopted. The students who were picked up for the study were first-year students. A google form was created for the questionnaire and circulated to check with what affective filter the first-year students enter the campus to pursue engineering.

A total of 70 engineers from different schools of engineering like Automation and Robotics, Bio-Technology, Civil, Computer Science, Electronics and Communication, Electronics and Electricals, Mechanical students were picked up for the study.

Attitude Motivation Test Battery In 1985, Gardner conceptualized the AMTB to measure various aspects of the affective filter, as they applied to English speaking Canadian students learning French in grades seven through eleven (see 
Appendix A for sample AMTB items). It measured five key affective factors, one of which was language anxiety. Gardner believed that general language anxiety was made up of two separate components: language class anxiety and language use anxiety (as cited by Bernaus et al., 2007).

The AMTB anxiety sub-test included only five items that assessed both of these components. The other eighteen subtests contained over one hundred items, which suggests that Gardner viewed language learner anxiety to be one of the less influential affective factors (Gardner, 1985). These items required students to respond to various statements using a 7-point Likert scale. Possible responses ranged from strongly disagree to strongly agree. All of the statements were positively worded because the Boards of Education managing the schools in which Gardner conducted his research insisted that positively worded items would be most easily understood by primary school children (1985).

Gardner recognized that positively wording the items may have resulted in higher levels of response bias and acquiescence, but defended the reliability and validity of the AMTB using Cronbach coefficient data. Since then, the AMTB has been translated and adapted by many researchers (Bernaus et al., 2007; Sánchez-Herrero \& Sanchez, 1992) to apply in different contexts. It remains one of the most cited and adapted measures for assessing language learner anxiety as part of affective filter multi-factor studies.

The final version of the AMTB used for this study measured the following 10 subscales:

1. Interest in foreign languages

2. Motivational intensity

3. English teaching evaluation

4. Attitudes towards learning English

5. Attitudes toward English-speaking people

6. Integrative orientation

7. Desire to learn English

8. English course evaluation

9. Instrumental orientation

10. English Class Anxiety

\begin{tabular}{|c|l|}
\hline \multicolumn{2}{|l|}{ AMTB } \\
\hline \multicolumn{3}{|c|}{ 1. Interest in foreign languages } \\
\hline 1 & $\begin{array}{l}\text { I wish I could speak many foreign languages } \\
\text { perfectly. }\end{array}$ \\
\hline 2 & $\begin{array}{l}\text { I wish I could read newspapers and magazines in } \\
\text { many foreign languages. }\end{array}$ \\
\hline 3 & $\begin{array}{l}\text { If I planned to stay in another country, I would try } \\
\text { to learn their language. }\end{array}$ \\
\hline 4 & $\begin{array}{l}\text { I enjoy meeting people who speak foreign } \\
\text { languages }\end{array}$ \\
\hline 5 & My interest in foreign languages is... \\
\hline
\end{tabular}

\section{AMTB}

2. Motivational intensity

\begin{tabular}{|c|l|}
\hline 1 & $\begin{array}{l}\text { I make a point of trying to understand all the } \\
\text { English I see and hear. }\end{array}$ \\
\hline 2 & $\begin{array}{l}\text { I keep up to date with English by working on it } \\
\text { almost every day. }\end{array}$ \\
\hline 3 & $\begin{array}{l}\text { When I have a problem understanding } \\
\text { something in my English class, I always ask my } \\
\text { teacher for help. }\end{array}$ \\
\hline 4 & I really work hard to learn English. \\
\hline 5 & $\begin{array}{l}\text { When I am studying English, I ignore } \\
\text { distractions and pay attention to my task. }\end{array}$ \\
\hline 6 & My motivation to learn English is \\
\hline
\end{tabular}

\begin{tabular}{|c|c|}
\hline \multicolumn{2}{|c|}{ AMTB } \\
\hline \multicolumn{2}{|r|}{ 3. English teaching evaluation } \\
\hline 1 & $\begin{array}{l}\text { I look forward to going to class because my } \\
\text { English teacher is good. }\end{array}$ \\
\hline 2 & $\begin{array}{l}\text { My English teacher is better than any of my other } \\
\text { teachers. }\end{array}$ \\
\hline 3 & $\begin{array}{l}\text { My English teacher has a dynamic and } \\
\text { interesting teaching style. }\end{array}$ \\
\hline 4 & $\begin{array}{l}\text { My English teacher is a great source of } \\
\text { inspiration to me. }\end{array}$ \\
\hline 5 & I really like my English teacher. \\
\hline 6 & My attitude toward my English teacher is \\
\hline
\end{tabular}

\begin{tabular}{|l|l|}
\hline \multicolumn{2}{|l|}{ AMTB } \\
\hline \multicolumn{2}{|c|}{ 4. Attitudes towards learning English } \\
\hline 1 & Learning English is really great \\
\hline 2 & I really enjoy learning English. \\
\hline 3 & $\begin{array}{l}\text { English is a very important part of the school } \\
\text { program. }\end{array}$ \\
\hline 4 & I plan to learn as much English as possible. \\
\hline 5 & I love learning English. \\
\hline 6 & My attitude toward learning English is \\
\hline
\end{tabular}

\begin{tabular}{|c|l|}
\hline \multicolumn{2}{|c|}{ AMTB } \\
\hline 1 & $\begin{array}{l}\text { I wish I could have many native English } \\
\text { speaking friends. }\end{array}$ \\
\hline 2 & $\begin{array}{l}\text { Native English people are very sociable and } \\
\text { kind. }\end{array}$ \\
\hline 3 & $\begin{array}{l}\text { Native English speakers have much to be proud } \\
\text { about because they have given the world much of } \\
\text { value. }\end{array}$ \\
\hline 4 & $\begin{array}{l}\text { I would like to know more native English } \\
\text { speakers. }\end{array}$ \\
\hline 5 & $\begin{array}{l}\text { The more I get to know native English speakers, } \\
\text { the more I like them }\end{array}$ \\
\hline 6 & You can always trust English speakers. \\
\hline 7 & $\begin{array}{l}\text { My attitude toward English speaking people } \\
\text { is }\end{array}$ \\
\hline
\end{tabular}

\section{AMTB}




\begin{tabular}{|c|l|}
\hline \multicolumn{2}{|c|}{ 6. Integrative orientation } \\
\hline 1 & $\begin{array}{l}\text { Studying English is important because it will } \\
\text { allow me to be more at ease with people who } \\
\text { speak English. }\end{array}$ \\
\hline 2 & $\begin{array}{l}\text { Studying English is important because it will } \\
\text { allow me to meet and converse with more and } \\
\text { varied people. }\end{array}$ \\
\hline 3 & $\begin{array}{l}\text { Studying English is important because it will } \\
\text { enable me to better understand and appreciate the } \\
\text { English way of life. }\end{array}$ \\
\hline 4 & $\begin{array}{l}\text { Studying English is important because I will be } \\
\text { able to interact more easily with speakers of } \\
\text { English. }\end{array}$ \\
\hline 5 & $\begin{array}{l}\text { My motivation to learn English in order to } \\
\text { communicate with English speaking people is }\end{array}$ \\
\hline
\end{tabular}

\begin{tabular}{|c|l|}
\hline \multicolumn{2}{|l|}{ AMTB } \\
\hline \multicolumn{2}{|l|}{ 7. Desire to learn English } \\
\hline 1 & $\begin{array}{l}\text { I have a strong desire to know all aspects of } \\
\text { English. }\end{array}$ \\
\hline 2 & $\begin{array}{l}\text { I want to learn English so well that it will } \\
\text { become natural to me. }\end{array}$ \\
\hline 3 & $\begin{array}{l}\text { I would like to learn as much English as } \\
\text { possible. }\end{array}$ \\
\hline 4 & I wish I were fluent in English. \\
\hline 5 & $\begin{array}{l}\text { If it were up to me, I would spend all of my } \\
\text { time learning English. }\end{array}$ \\
\hline 6 & My desire to learn English is \\
\hline
\end{tabular}

\begin{tabular}{|c|l|}
\hline \multicolumn{2}{|l|}{ AMTB } \\
\hline 1 & $\begin{array}{l}\text { 8. English course evaluation } \\
\text { class and less in other classes. }\end{array}$ \\
\hline 2 & $\begin{array}{l}\text { I enjoy the activities of our English class much } \\
\text { more than those of my other classes. }\end{array}$ \\
\hline 3 & $\begin{array}{l}\text { I like my English class so much, I look forward } \\
\text { to studying more English in the future. }\end{array}$ \\
\hline 4 & $\begin{array}{l}\text { I look forward to the time I spend in English } \\
\text { class. }\end{array}$ \\
\hline 5 & English is one of my favourite courses. \\
\hline 6 & My attitude toward my English course is \\
\hline
\end{tabular}

\begin{tabular}{|c|l|}
\hline \multicolumn{2}{|l|}{ AMTB } \\
\hline \multicolumn{2}{|c|}{ 9. Instrumental orientation } \\
\hline 1 & $\begin{array}{l}\text { Studying English is important because I will } \\
\text { need it for my career. }\end{array}$ \\
\hline 2 & $\begin{array}{l}\text { Studying English is important because it will } \\
\text { make me more educated. }\end{array}$ \\
\hline 3 & $\begin{array}{l}\text { Studying English is important because it will } \\
\text { be useful in getting a good job. }\end{array}$ \\
\hline 4 & $\begin{array}{l}\text { Studying English is important because other } \\
\text { people will respect me more if I know English. }\end{array}$ \\
\hline 5 & $\begin{array}{l}\text { My motivation to learn English for practical } \\
\text { purposes (e.g. to get a job, a better salary, better }\end{array}$ \\
\hline
\end{tabular}

\begin{tabular}{|c|c|}
\hline & grades) is: \\
\hline \multicolumn{2}{|c|}{ AMTB } \\
\hline \multicolumn{2}{|r|}{ 10. English Class Anxiety } \\
\hline 1 & $\begin{array}{l}\text { It embarrasses me to volunteer answers in my } \\
\text { English Class. }\end{array}$ \\
\hline 2 & $\begin{array}{l}\text { I never feel quite sure of myself when I am } \\
\text { speaking in my English Class. }\end{array}$ \\
\hline 3 & $\begin{array}{l}\text { I will feel that the other students speak English } \\
\text { better than I do. }\end{array}$ \\
\hline 4 & $\begin{array}{l}\text { I get nervous and confused when I am speaking in } \\
\text { my English Class. }\end{array}$ \\
\hline 5 & $\begin{array}{l}\text { I am afraid the other students will laugh at me } \\
\text { when I speak in English. }\end{array}$ \\
\hline
\end{tabular}

(Table 5: AMTB Questionnaire with its subscales)

\section{The Stacked Cylinder Representation of Data:}

The AMTB questionnaire was sent through google form to 70 students. The students were asked to give their opinion about each statement by circling the alternative next to it, which best indicates the extent to which they agree or disagree. The students were informed to provide answers to all of the statements mentioned as a part of the AMTB questionnaire. The scale given for reference was,

\begin{tabular}{|l|l|}
\hline Strongly disagree & 1 \\
\hline Moderately disagree & 2 \\
\hline Slightly disagree & 3 \\
\hline Neutral & 4 \\
\hline Slightly agree & 5 \\
\hline Moderately agree & 6 \\
\hline Strongly agree & 7 \\
\hline
\end{tabular}

(Table 6: Scales for Analysis)

The representation here shows the average of the sample selected from every school of engineering inclined positively towards the ten subscales of AMTB picked up for the analysis. The representation will be in the following flow.
1. Interest in foreign languages
2. Motivational intensity
3. English teaching evaluation
4. Attitudes towards learning English
5. Attitudes toward English-speaking people
6. Integrative orientation
7. Desire to learn English
8. English course evaluation
9. Instrumental orientation
10. English Class Anxiety
1. Interest in foreign languages (Average students of the sample inclined positively)




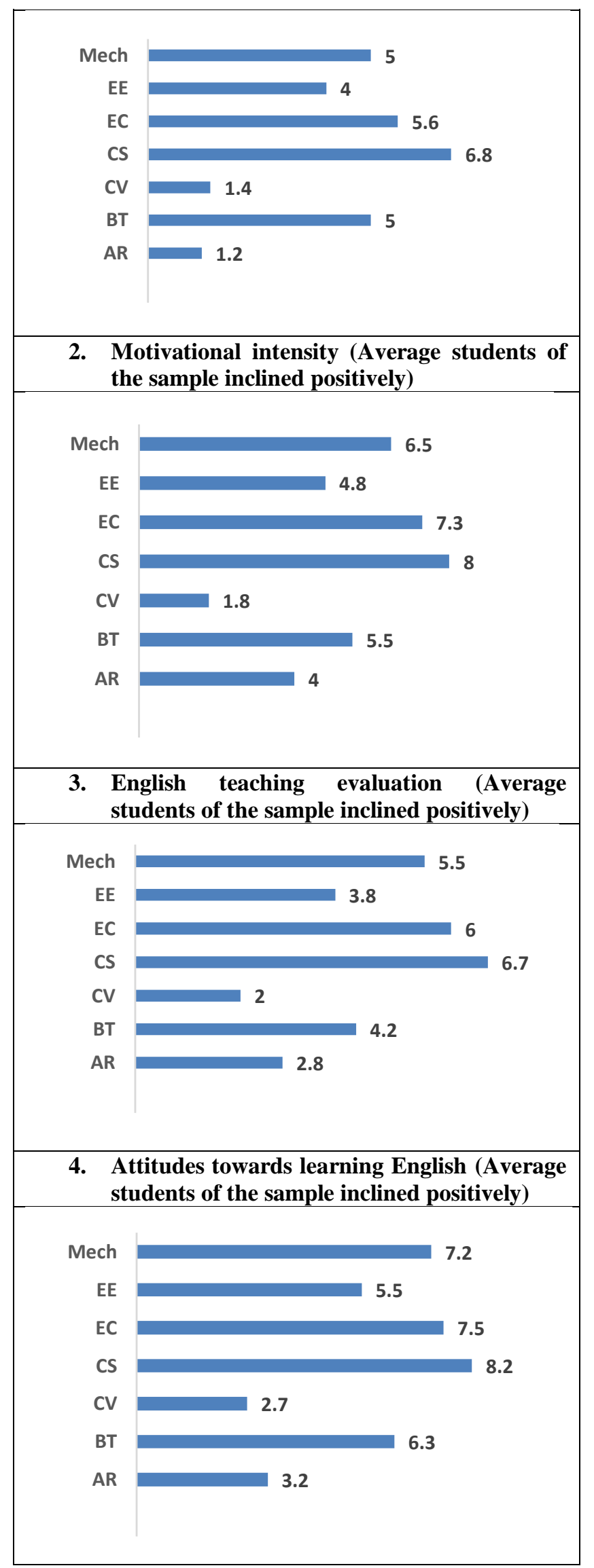

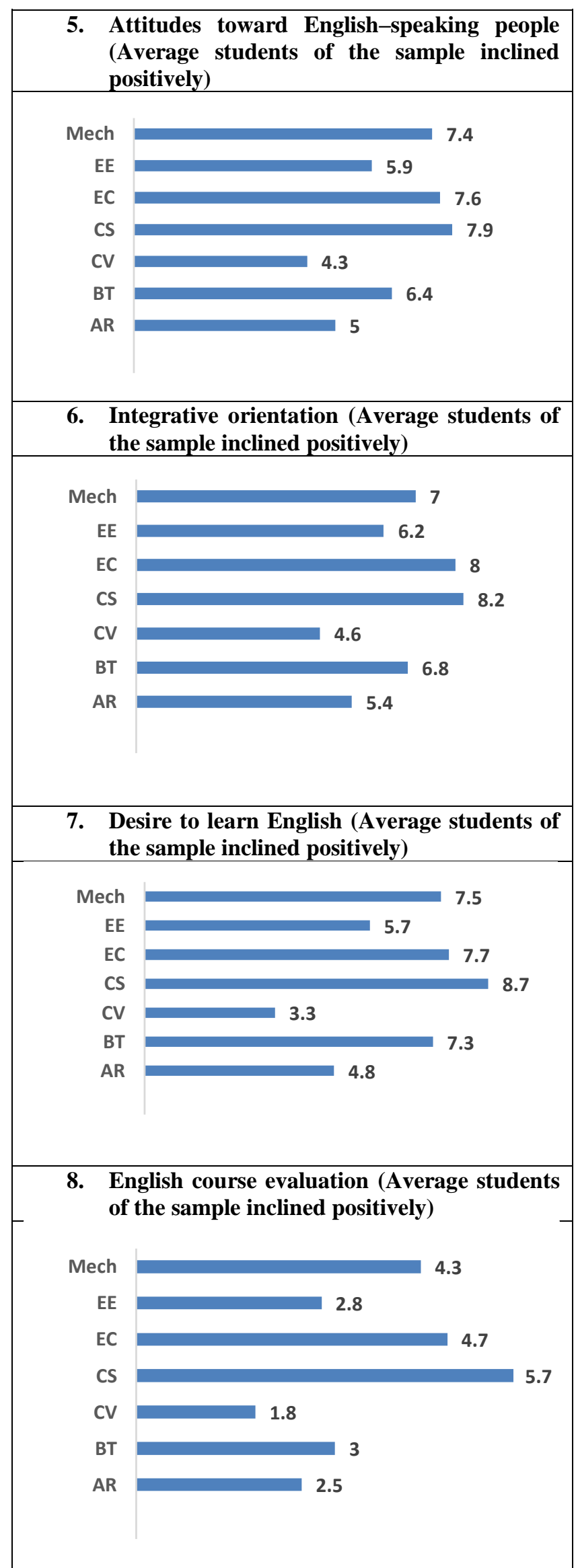




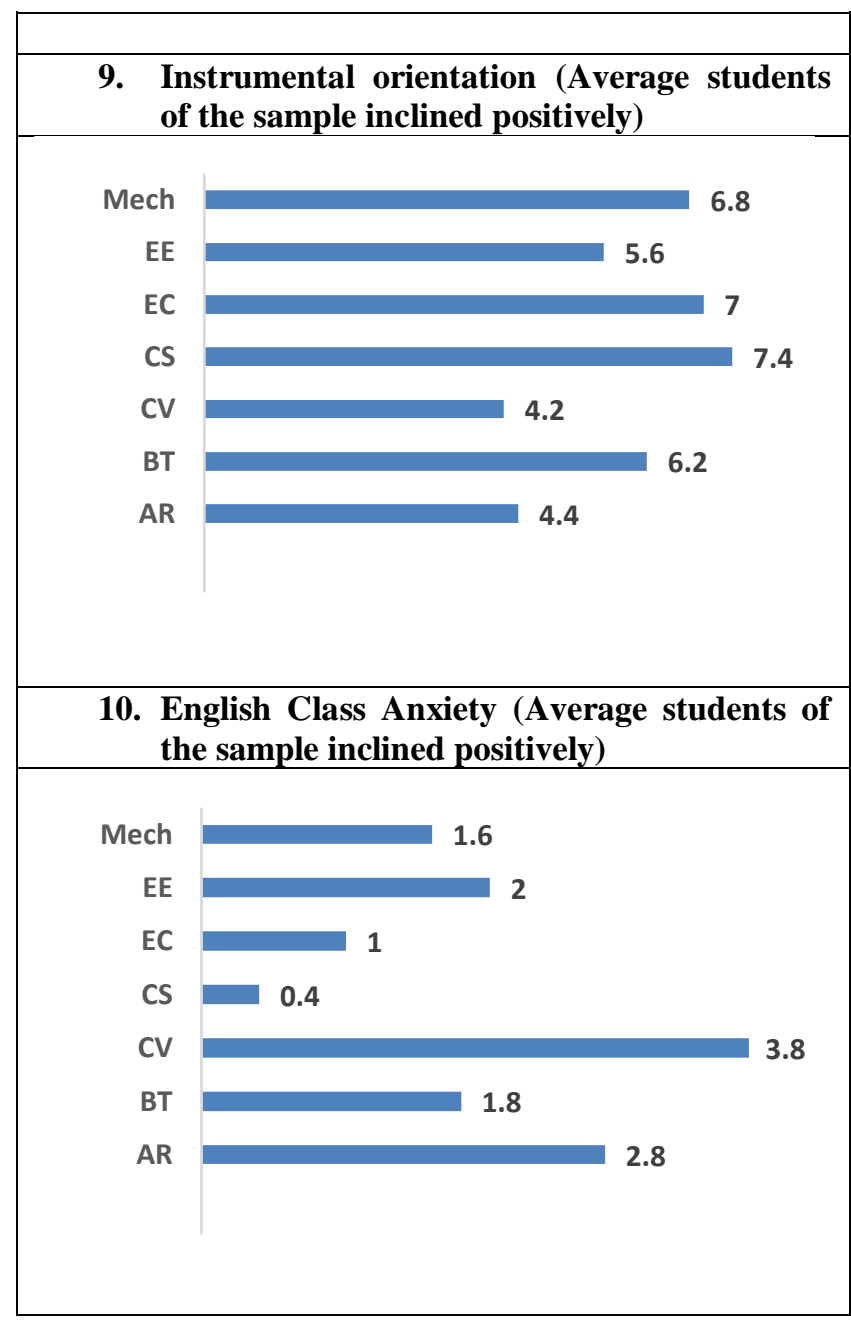

(Table 5: Clustered Bar representation of the average of sample students inclined positively)

The following representation shows the comparison of all the ten subscales for all the schools of engineering. This comparison give us the glimpse of all the sub scales and all the school of engineering.

Comparison of all the subscales against the schools of engineering.

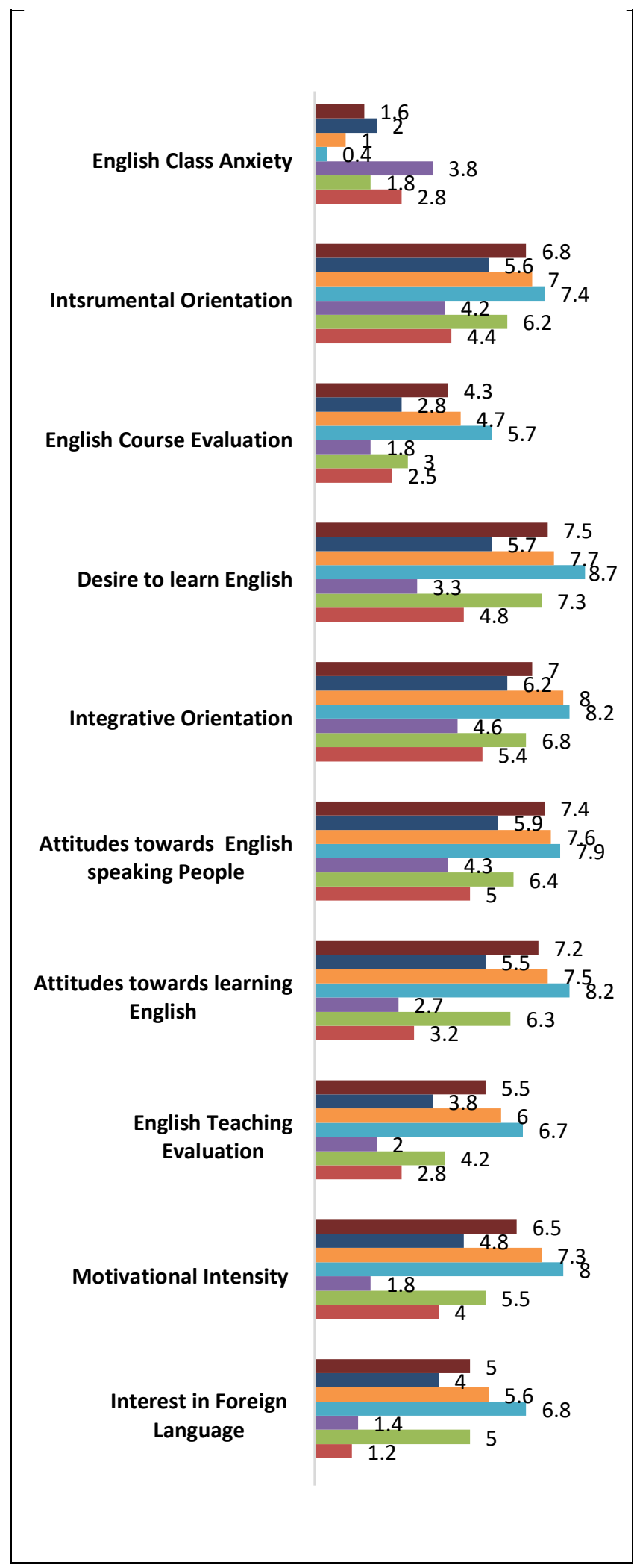

(Table 6: Comparison of all the subscales against the schools of engineering)

Inferences: 
The inferences drawn out from the experiment are as follows: The bunch of students from the respective schools of engineering show positive correlation between attitude and motivation in learning English language. The high levels of attitude and motivation towards the English language descend from the computer science students to civil students.
1. Computer Science
2. Electronics and Communication
3. Mechanical
4. Bio - Technology
5. Electronics and Electricals
6. Automation and Robotics
7. Civil

\section{Conclusions}

The modules of the courses on English language Skills should be designed meticulously considering the affective filters like attitude and motivation of the students towards the English language. This will help the classroom environment conducive for the students to ingrain the language easily.

\section{Future Scope}

The study should be done for all the students of engineering across all the four years. This information will give a very meaningful insight in designing right modules for right students.

\section{References}

Ahmed. Shameem (2015), Attitudes towards English Language Learning among EFL Learners at UMSKAL, The Journal of Education and Practice, Vol 6, No.18

Frutiger.Megan (2018) Adapting Tools To Measure Students' Affective Filter for the Elementary DualImmersion Context, Digitalcommons@Hamline, Hamline University Press.

Sandoval-Pinada, Angelica (2011) Attitude, Motivation and English language Learning in a Mexican College Context, an electronic dissertation, The University of Arizona.

Rian. Joel (2007), Attitudes towards English and English Learning at three rural Japanese middle schools: A preliminary survey, Macquarie University, Australia 